\title{
Covid-19 as occupational disease in healthcare workers: a brief review of cases in the Clinical Hospital Centre Rijeka, Croatia
}

\author{
Hrvoje Lalić ${ }^{1,2}$ \\ ${ }^{1}$ Community Health Centre of Primorje-Gorski Kotar Count, Rijeka, Croatia \\ ${ }^{2}$ University of Rijeka Faculty of Medicine, Rijeka, Croatia
}

[Received in January 2021; Similarity Check in January 2021; Accepted in September 2021]

\begin{abstract}
The coronavirus disease 19 (COVID-19) pandemic has had a tremendous impact on every facet of private life and work organisation in virtually all social and economic sectors worldwide. People who stand on the first line of defence are healthcare workers (HCWs) risking exposure to infected patients. However, even though they are often affected by COVID-19 and associated somatic and mental health problems, COVID-19 as a new illness was not immediately acknowledged as occupational disease. This is why several groups of HCWs contacted their occupational medicine physicians in 2020 with a request to register the infection with SARS-CoV-2 as occupational disease. In an attempt to support their appeals and show that hospital workers have a high occupational risk of COVID-19, this study presents COVID-19 incidence and symptoms in 100 employees working at 11 clinics of the Clinical Hospital Centre (CHC) Rijeka, Croatia from 1 June to end December 2020. All of them were infected with SARS-CoV-2 and took sick leave, which lasted 13.6 2.6 days in average. This study also looks into the role of occupational medicine physicians in prospective monitoring of acute and long-acting consequences of COVID-19 that might occur in HCWs.
\end{abstract}

KEY WORDS: incidence; occupational medicine; SARS-CoV-2; symptoms

Originating from Wuhan in China, the coronavirus disease-19 (COVID-19) reached global spread in just a few months. According to recent information issued by the World Health Organization (WHO), the number of affected persons surpassed 200 million in the world and 380 thousand in Croatia. The pandemic caused over 4.5 million deaths and resulted in long-lasting psychopathological and socioeconomic consequences owing to the lockdowns and epidemiological measures implemented to prevent the spread of infection. The disease created a heavy burden on health care and its workers (HCWs), who are in direct contact with infected patients and often affected by COVID-19 and associated somatic and mental health problems (1-7).

Even though they work on the first line of defence, however, COVID-19 had not been recognised as occupational disease in Croatia until the Croatian Medical Association's Society of Occupational Health called attention to the issue. Until then, in 2020, many HCWs requested their occupational medicine $(\mathrm{OM})$ physicians to help them prove the work-related character of their SARSCoV-2 infection and obtain full salary compensation for

Corresponding author: Hrvoje Lalić, Dom zdravlja Primorsko-goranske županije, Ive Marinkovića 11, 51000 Rijeka, Croatia

E-mail: hlalic@inet.hr sick leaves. These cases also provided important information about the symptoms and initial spread of COVID-19 among Croatian HCWs. In this context, Žaja et al. (8) collected data from HCWs in eight Croatian counties and reported that hospital nurses and laboratory technicians ran a higher risk of SARS-CoV-2 infection.

In an attempt to contribute to this knowledge, we made a short overview of the incidence of COVID-19 symptoms in 100 employees working at the Clinical Hospital Centre (CHC) Rijeka during the coronavirus outbreak in Croatia in 2020 .

\section{MATERIAL AND METHODS}

\section{Participants, data collection, and analysis}

The incidence of COVID-19 symptoms was analysed in 100 medical doctors, nurses, laboratory technicians, cleaners, and other professions employed in various departments of CHC Rijeka who requested their OM specialist to acknowledge their COVID-19 as occupational disease between 1 June 2020 and 31 December 2020. All of them had been on sick leave due to SARS-CoV-2 infection confirmed by PCR test results obtained at the University of Rijeka Faculty of Medicine. 
Information about their workplace, age, gender, COVID-19 symptom severity, and duration of sick leave was collected through a questionnaire made for that purpose, in which they described the course of their illness and the symptoms associated with COVID-19, such as fever and respiratory, olfactory, gustatory, and other problems (8-10). The answers and PCR test results were received by e-mail or post after the participants completed their sick leave. They were then divided into 11 groups by workplace (surgery, emergency department, anaesthesiology, radiology, transfusion medicine, internal medicine, oncology, microbiology, dermatology, maintenance and administration, hospital pharmacy, ophthalmology, and clinic for infectious diseases) and classified by symptom severity as asymptomatic, mild, or moderate, depending on the number of self-reported COVID-19-related clinical symptoms. Symptoms were considered mild in participants who reported subfebrile body temperature $\left(37.1-37.2^{\circ} \mathrm{C}\right)$ and mild fatigue over a day or two without other symptoms. Moderate symptoms were considered those involving temperatures reaching $38-39{ }^{\circ} \mathrm{C}$ and prevalent fatigue, general weakness, dyspnoea, cough, stomach ache, diarrhoea, low back and other musculoskeletal pain, which lasted a week or so. Asymptomatic were those who reported no symptoms but were in self-isolation due to direct contact with infected patients and had a positive PCR test. None of the participants reported severe symptoms.

Participation was voluntary and the collected data were part of routine OM practice. The study was approved by the CHC Ethics Committee (Decision No. 01-47/3-3-21) and conducted in accordance with the principles of the Declaration of Helsinki.

\section{Statistical analysis}

The data are presented as number of cases, percentage, and incidence by department. COVID-19 incidence was calculated from the number of participant and the total number of employees in each department.

The statistical analyses were performed using Statistica version 12 (StatSoft Inc., Tulsa, OK, USA). Differences between parametric and nonparametric groups were assessed with Student's $t$-test or Mann-Whitney $U$ test, respectively. Parametric data are given as arithmetic means \pm standard deviation (SD). Statistical differences with $\mathrm{p}<0.05$ were considered significant.

\section{RESULTS AND DISCUSSION}

Of the 100 HCWs with COVID-19 73 were women and 27 men. According to profession, $42 \%$ were laboratory technicians, $34 \%$ nurses, $18 \%$ physicians, $4 \%$ cleaners, and $2 \%$ other professions. The average age of all infected employees was $43.2 \pm 6.5$ (range 22-64) years, and most (63\%) developed mild symptoms (Table 1). Most participants worked in the surgery department $(\mathrm{N}=17)$, but the highest incidence of infection was in the microbiology department (25\%) (Table 1). This suggests that some departments entail a higher risk of exposure to contagious material and infected people (patients and colleagues) or take less precaution than other departments. We found no significant correlation between gender and COVID-19 incidence (data not shown).

Table 1 Characteristics of COVID-19 in healthcare workers at the Clinical Hospital Centre Rijeka. Croatia (from 1 June to 31 December 2020)

\begin{tabular}{|c|c|c|c|c|c|c|c|c|c|}
\hline \multirow{3}{*}{ Departments } & \multirow{3}{*}{$\begin{array}{l}\text { No. of } \\
\text { cases }\end{array}$} & \multirow{3}{*}{$\begin{array}{l}\text { COVID-19 } \\
\text { incidence } \\
(\%)\end{array}$} & \multirow{3}{*}{$\begin{array}{l}\text { Men } \\
(\mathrm{N})\end{array}$} & \multirow{3}{*}{$\begin{array}{l}\text { Women } \\
\text { (N) }\end{array}$} & \multirow{3}{*}{$\begin{array}{c}\text { Age (years) } \\
\text { mean } \pm \text { SD }\end{array}$} & \multirow{3}{*}{$\begin{array}{c}\text { Sick leave } \\
\text { (days) } \\
\text { mean } \pm \text { SD }\end{array}$} & \multicolumn{3}{|c|}{ COVID-19 symptom severity } \\
\hline & & & & & & & $\begin{array}{c}\text { No } \\
\text { symptoms }\end{array}$ & Mild & Moderate \\
\hline & & & & & & & \multicolumn{3}{|c|}{ N (\%) of cases } \\
\hline Surgery & 17 & 5.9 & 3 & 14 & $51.1 \pm 9.5$ & $18.1 \pm 10.2$ & 0 & $\begin{array}{c}11 \\
(64.7)\end{array}$ & $6(35.3)$ \\
\hline Emergency & 7 & 5.7 & 6 & 1 & $32.3 \pm 4.3 * *$ & $18.0 \pm 8.3$ & $3(42.9)$ & $3(42.9)$ & $1(14.3)$ \\
\hline Anaesthesiology & 9 & 4.1 & 3 & 6 & $37.8 \pm 13.1$ & $13.0 \pm 9.8$ & 0 & $8(88.9)$ & $1(11.1)$ \\
\hline $\begin{array}{l}\text { Transfusion } \\
\text { medicine }\end{array}$ & 6 & 6.8 & 0 & 6 & $34.2 \pm 11.3$ & $13.2 \pm 4.4$ & $2(33.3)$ & $4(66.7)$ & 0 \\
\hline $\begin{array}{l}\text { Internal } \\
\text { medicine }\end{array}$ & 10 & 13.0 & 1 & 9 & $50.1 \pm 9.8$ & $14.0 \pm 4.4$ & $2(20)$ & $6(60.0)$ & $2(20.0)$ \\
\hline Oncology & 11 & 16.2 & 0 & 11 & $45.7 \pm 14.7$ & $10.8 \pm 4.0$ & 0 & $5(45.5)$ & $6(54.5)$ \\
\hline Microbiology & 8 & 25.0 & 0 & 8 & $37.6 \pm 13.8$ & $12.4 \pm 4.0$ & 0 & $8(100)$ & 0 \\
\hline Radiology & 12 & 5.8 & 7 & 5 & $41.3 \pm 11.4$ & $13.1 \pm 8.6$ & 0 & $7(58.3)$ & $5(41.7)$ \\
\hline Dermatology & 5 & 11.4 & 2 & 3 & $50.0 \pm 12.7$ & $10.2 \pm 1.1$ & 0 & $5(100)$ & 0 \\
\hline Services & 9 & 9.4 & 5 & 4 & $46.3 \pm 12.2$ & $16.1 \pm 5.3$ & 0 & $5(55.6)$ & $4(44.4)$ \\
\hline Other* & 6 & 4.6 & 0 & 6 & $48.8 \pm 9.5$ & $11.0 \pm 4.5$ & $3(50)$ & $1(16.7)$ & $2(33.3)$ \\
\hline Total & 100 & $9.8 \pm 6.3$ & 27 & 73 & $43.2 \pm 6.5$ & $13.6 \pm 2.6$ & 10 & 63 & 27 \\
\hline
\end{tabular}

* departments with $<3$ COVID-19 cases (hospital pharmacy, ophthalmology, and clinic for infectious diseases); ** $<<0.01$ 
Table 2 Distribution of COVID-19 symptoms by department

\begin{tabular}{|c|c|c|c|c|c|c|c|c|c|}
\hline \multirow[b]{2}{*}{ Departments } & \multirow[b]{2}{*}{$\begin{array}{l}\text { No. of } \\
\text { cases }\end{array}$} & \multicolumn{3}{|c|}{ Temperature } & \multirow[b]{2}{*}{ Cough } & \multirow[b]{2}{*}{ Chills } & \multirow[b]{2}{*}{$\begin{array}{c}\text { No } \\
\text { smell }\end{array}$} & \multirow[b]{2}{*}{$\begin{array}{l}\text { No } \\
\text { taste }\end{array}$} & \multirow[b]{2}{*}{$\begin{array}{l}\text { Intestinal } \\
\text { symptoms }\end{array}$} \\
\hline & & $\begin{array}{c}\text { Low } \\
\left(37.1-37.2^{\circ} \mathrm{C}\right)\end{array}$ & $\begin{array}{l}\text { Moderate } \\
\left(38-39{ }^{\circ} \mathrm{C}\right)\end{array}$ & $\begin{array}{c}\text { High } \\
\left(>39^{\circ} \mathrm{C}\right)\end{array}$ & & & & & \\
\hline Surgery & 17 & 4 & 11 & 2 & 4 & 4 & 9 & 7 & 1 \\
\hline Emergency & 7 & 6 & 1 & 0 & 2 & 1 & 1 & 0 & 0 \\
\hline Anaesthesiology & 9 & 6 & 3 & 0 & 1 & 1 & 4 & 4 & 0 \\
\hline $\begin{array}{l}\text { Transfusion } \\
\text { medicine }\end{array}$ & 6 & 3 & 2 & 1 & 0 & 0 & 4 & 2 & 0 \\
\hline Internal medicine & 10 & 2 & 4 & 2 & 1 & 5 & 5 & 5 & 0 \\
\hline Oncology & 11 & 4 & 4 & 3 & 0 & 3 & 2 & 2 & 2 \\
\hline Microbiology & 8 & 6 & 2 & 0 & 1 & 2 & 5 & 5 & 0 \\
\hline Radiology & 12 & 5 & 5 & 2 & 1 & 1 & 1 & 1 & 0 \\
\hline Dermatology & 5 & 3 & 2 & 0 & 1 & 1 & 1 & 1 & 0 \\
\hline Services & 9 & 3 & 4 & 2 & 1 & 5 & 2 & 1 & 2 \\
\hline Other* & 6 & 1 & 1 & 1 & 1 & 2 & 2 & 1 & 0 \\
\hline Total & 100 & 43 & 39 & 13 & 13 & 25 & 36 & 29 & 5 \\
\hline
\end{tabular}

* departments with <3 COVID-19 cases (hospital pharmacy, ophthalmology, and clinic for infectious diseases)

Table 2 shows the distribution of symptoms typical of SARS-CoV-2 infection similarly to other reports (8-10). In fact, all of our results are in high agreement with the recently published data of Žaja et al. (8) for a similar population, who reported that most (78\%) COVID-19 patients were nurses or laboratory technicians working in hospitals and that they predominantly exhibited the mild form of the disease.

Our data also show that the sick leaves of our participants lasted 13.6 \pm 2.6 days (Table 1). As soon as the SARS-CoV-2 infection in HCWs was classified as occupational disease, the Croatian Health Insurance Fund allocated full benefits, including fully paid sick leave and psychological support to the affected HCWs.

Hopefully this short overview has succeeded in highlighting the difficult position in which HCWs in $\mathrm{CHC}$ Rijeka found themselves during the initial spread of COVID and in underlining the importance of OM physicians in helping to resolve post COVID-19 issues.

\section{REFERENCES}

1. Zhang W-R, Wang K, Yin L, Zhao W- F, Xue Q, Peng M, Min BQ, Tian Q, Leng H-X, Du J-L, Chang H, Yang Y, Li W, Shangguan F-F, Yan T-Y, Dong H-Q, Han Y, Wang Y-P, Cosci F, Wang H-X. Mental health and psychological problems of medical health workers during the Covid-19 epidemic in China. Psychoter Psychosom 2020;89:242-50. doi: 10.1159/0000507639

2. Walton M, Murray E, Christian DC. Mental health care for medical staff and affiliated healthcare workers during the Covid-19 pandemic. Eur Hearth J Acute Cardiovasc Care 2020;9:241-7. doi: 101177/2048872620922795

3. Bohlken J, Schömig F, Lemke RM, Pumberger M, RiedelHeller SG. COVID-19-Pandemie: Belastungen des medizinischen Personals. Ein kurzer aktueller Review [Covid-19 pandemic: Stress experience of healthcare workers
- a short current review, in German]. Psychiatr Prax 2020;47:190-7. doi: 10.1055/a-1159-5551

4. Bradley AE, Strickland JR, Dale AM, Hayibor L, Page E, Duncan JG, Kannampallil T, Gray DL. Work-related and personal factors associated with mental well-being during the Covid-19 response: survey of health care and other workers. J Med Internet Res 2020;22(8):e21366. doi: $10.2196 / 21366$

5. Stelnicki AM, Carleton RN, Reichert C. Nurses' mental health and well-being: Covid-19 impacts. Can J Nurs Res 2020;52:237-9. doi: 10.1177/0844562120931623

6. Di Tella M, Romeo A, Benfante A, Castelli L. Mental health of healthcare workers during the Covid-19 pandemic in Italy. J Eval Clin Pract 2020;26:1583-7. doi: 10.1111/jep.13444

7. Carmassi C, Foghi C, Dell Óste V, Cordone A, Bertelloni CA, Bui E, Dell'Ossoa L. PTSD symptoms in healthcare workers facing the three coronavirus outbreaks: What can we expect after the Covid-19 pandemic. Psychiatry Res 2020;292:113312. doi: 10.1016/j.psychres.2020.113312

8. Žaja R, Kerner I, Macan J, Milošević M. Characteristics of work-related COVID-19 in Croatian healthcare workers: a preliminary report. Arh Hig Rada Toksikol 2021;72:36-41. doi: 10.2478/aiht-2021-72-3530

9. Haldrupp M, Illerman Johansen M, Fjaeldstad AW. [Anosmia and ageusia as primary symptoms of Covid-19. Case Reports, in Danish]. Ugeskr Laeger 2020;182(18):V04200205. PMID: 32400371

10. Esakadari H, Nabi-Afjadi M, Fakkari-Afjadi J, Farahmandian N, Miresmaeli SM, Bahreini M. A comprehensive review of Covid-19 characteristics. Biol Proced Online 2020;22:19. doi: 10.1186/s12575-020-00128-2

11. Troyer EA, Kohn JN, Hong S. Are we facing a crashing wave of neuropsychiatric sequelae of COVID-19? Neuropsychiatric symptoms and potential immunologic mechanisms. Brain Behav Immun 2020;87:34-9. doi: 101016/j.bbi.2020.04.027

12. Rogers JP, Chesney E, Oliver D, Pollak TA, McGuirre P, Fusar-Polli P, Zandi MS, Lewis G, David AS. Psychiatric and neuropsychiatric presentations associated with severe coronavirus infections: a systematic review and meta-analysis with comparison to the COVID-19 pandemic. Lancet Psychiatry 2020;7:611-27. doi: 101016/S22150366(20)30203-0 


\section{COVID-19 kao profesionalna bolest zdravstvenih radnika - kratki pregled slučajeva u Kliničkom bolničkom} centru Rijeka

Bolest uzrokovana koronavirusom (COVID-19) pandemija je koja ugrožava živote mnogih pojedinaca i organizacija u gotovo svim društvenim i gospodarskim sektorima diljem svijeta. Pri tome, međutim, najviše stradavaju ljudi medicinske struke, koji su na prvoj crti obrane izloženi bolesnicima i zaraznom materijalu. Kao česte žrtve virusa, oni su izloženi brojnim somatskim i psihosocijalnim problemima, no kako početkom 2020. godine infekcija SARS-CoV-2 nije još bila uvrštena među profesionalne bolesti, brojni zdravstveni radnici zatražili su od medicine rada priznavanje COVIDA-19 kao profesionalne bolesti. Kako bismo poduprli njihove opravdane zahtjeve, napravili smo kratak osvrt na zdravstveno stanje 100 zdravstvenih radnika zaraženih SARS-CoV-2, koji su od lipnja do kraja prosinca 2020. radili u pojedinim odjelima Kliničkoga bolničkog centra (KBC) u Rijeci. Opisali smo incidenciju i simptome COVID-19 u 11 kliničkih odjela KBC-a i naglasili važnu ulogu medicine rada u procjenjivanju akutnih i mogućih dugotrajnih posljedica COVIDA-19, koje se učestalo pojavljuju u zdravstvenih radnika.

KLJUČNE RIJEČI: incidencija; medicina rada; simptomi; SARS-CoV-2 